Article

\title{
Upgrading of Mixed Food Industry Side-Streams by Solid-State Fermentation with P. ostreatus
}

\author{
Theodoros Aggelopoulos ${ }^{1}$, Argyro Bekatorou ${ }^{1, *}$, Stavros Plessas ${ }^{2}$, Athanasios A. Koutinas ${ }^{1}$ and \\ Poonam Nigam ${ }^{3}$ \\ 1 Department of Chemistry, University of Patras, Patras 26500, Greece; thaggelop@upatras.gr (T.A.); \\ a.a.koutinas@upatras.gr (A.A.K.) \\ 2 Laboratory of Microbiology, Biotechnology and Hygiene, Department of Agricultural Development, \\ Democritus University of Thrace, 193 Pantazidou Str., Orestiada 68200, Greece; splessas@agro.duth.gr \\ 3 School of Biomedical Sciences, University of Ulster, Coleraine BT52 1SA, UK; p.singh@ulster.ac.uk \\ * Correspondence: abekatorou@upatras.gr; Tel.: +30-2610962964; Fax: +30-2610997105
}

Received: 6 February 2018; Accepted: 28 March 2018; Published: 1 April 2018

\begin{abstract}
In the frame of efforts to exploit agroindustrial side-streams and wastes (AISS) for added-value products that are based on single cell protein (SCP), mixed substrates consisting of brewer's spent grains (BSG), malt spent rootlets (MSR), cheese whey, molasses, orange, and potato pulps, were used for growth of the edible mushroom Pleurotus ostreatus. The substrates were mixed in various combinations, and were used for P. ostreatus growth at various conditions. The substrate, for which the highest sugar consumption, protein increase, and mycelium yield were observed, consisted of $20 \mathrm{~mL}$ molasses ( $4^{\circ}$ Baume density), $20 \mathrm{~mL}$ potato pulp, $5 \mathrm{~mL}$ whey, $5 \mathrm{~mL}$ orange pulp, $30 \mathrm{~g}$ BSG, and $5 \mathrm{~g}$ MSR (at $25^{\circ} \mathrm{C}$ and substrate $\mathrm{pH}$ 4). The mycelium-enriched product was analyzed for protein, fat, minerals $(\mathrm{Ca}, \mathrm{Mg}, \mathrm{Fe}, \mathrm{Cu})$, and aroma volatile compounds, indicating the potential for use as nutritious supplement for food, feed, or microbiology uses. The product was also autolyzed, freeze-dried, powdered, and analyzed for total ribonucleic acid content, showing the potential for use as a commercial natural food flavor enhancer.
\end{abstract}

Keywords: Agroindustrial side-streams; Pleurotus ostreatus; protein; volatiles; autolysis; RNA content; natural food additive

\section{Introduction}

Agro-industrial wastes and side-streams (AISS), which are produced in large amounts worldwide, are usually rich in fermentable components. Specifically, food industry side-streams, such as brewer's spent grains (BSG) and malt spent rootlets (MSR) from breweries, wasted fruits and vegetables form agricultural production, landfills, restaurant wastes, etc., whey from the dairy industries, and molasses from the sugar industries, have the high potential for biotechnological utilization. However, apart from molasses, they are used in limited amounts as livestock feed or are discarded in the environment since their high organic load makes biological treatment impossible [1-10]. Bio-utilization of these materials and the conversion to products of added-value is, therefore, of great importance from both economical and environmental points of view. Single cell protein (SCP) production has been the subject of extensive research mainly for the production of animal feeds that are enriched in protein by microbial treatment of various AISS using both submerged $(\mathrm{SmF})$ and solid-state fermentation (SSF) processes. The most common examples of food grade SCP are baker's, brewer's, and distiller's yeasts, as well as food and feed supplements (as protein and vitamin sources and flavor enhancers). Molasses is an ideal carbon source that is commonly added to other substrates that contain low amounts of fermentable sugar, in order to facilitate their bioconversion $[7,9,10]$. Whey also has a huge 
potential for bioconversion to added-value products, such as food additives, protein, SCP, organic acids, enzymes, bioethanol, etc. $[6,9,10]$. The development of efficient and cost effective processes for its exploitation is a great scientific and industrial challenge, since it is generated in large amounts and has a high organic load. BSG and MSR can both be treated with cellulolytic, amylolytic, and/or ligninolytic species, to produce protein enriched livestock feeds, or other products of added-value. The use of BSG for such applications is limited but with promising results, while MSR have not been very widely exploited $[3-5,9,10]$. The exploitation of the above AISS for SCP production of various species, such as Kluyveromyces marxianus, kefir, and Saccharomyces cerevisiae, was recently reported $[9,10]$. A promotional effect of the addition of orange pulp was shown during a SmF process using mixed substrates of orange pulp, cheese whey, molasses, and potato pulp. Specifically, a 2- to 3-fold increase of cell mass was observed in the presence of orange pulp. Likewise, the promotional effect of BSG on cell growth during SSF of mixtures containing BSG, whey, molasses, potato pulp, MSR, and orange pulp, was also shown. The K. marxianus and S. cerevisiae growth was enhanced by three-fold and two-fold, respectively, in these substrates, thus proving their suitability for SCP production without need for synthetic nutrients $[9,10]$. Therefore, the mixed AISS can be used for low cost SCP production, achieving at the same time waste valorization and minimization.

The most studied food flavor enhancer is monosodium glutamate (MSG), although it has been accused for undesirable health effects, including the so-called Chinese restaurant syndrome [11-13]. Substitution of MSG with a safer natural flavor enhancer has been the subject of many research efforts based on the use of low cost biotechnological products, such as autolyzed microbial extracts [14,15]. Autolysis is a degradation process that produces soluble peptides, amino acids, nucleotides, and amino acid derivatives. Autolyzed SCPs can also be used as low cost extracts to replace the expensive commercial ones that are used in synthetic growth media. In this study, the enrichment of six AISS (BSG, MSR, molasses, whey, potato, and orange pulp) by SSF with Pleurotus ostreatus is described, as well as the autolysis and the proximate analysis of the produced SCP for potential use as multipurpose nutritious extract.

\section{Materials and Methods}

\subsection{Materials}

Cheese whey was obtained from the Agricultural Cooperatives Union of Kalavryta (Achaia province, Greece). Molasses was supplied by the B.G. Spiliopoulos S.A. alcohol distillery (Patras, Greece). BSG and MSR were supplied by the Athenian Brewery S.A. (member of the Heineken NV group, Patras, Greece). Their proximate composition has been reported in previous studies $[5,9,10]$. BSG were homogenized by blending and MSR were sieved to produce a fine powder. Sterilization of the substrates was done at $120^{\circ} \mathrm{C}$ for $15 \mathrm{~min}$. The potatoes and oranges were obtained from a local market. The external yellow exocarp of orange skins was removed and the fruit were blended to produce the whole orange pulp. In this pulp water was added at a ratio of 1:1 (by weight). In the same manner, the potato pulp was produced and diluted with two parts water (by weight).

\subsection{P. ostreatus Growth on Mixed AISS by SSF}

The edible fungus P. ostreatus was obtained by a local market and was grown on Malt Extract Agar (MEA). Specifically, cuttings with basiodispores were used to inoculate the medium in Petri dishes, which were then incubated at $25^{\circ} \mathrm{C}$ for $5-7$ days until white, fluffy mycelia appeared. For the study of P. ostreatus growth by SSF, 25 different mixtures of the AISS were used (Table 1). 
Table 1. Composition of the mixed agroindustrial side-streams and wastes (AISS) substrates before and after solid-state fermentation (SSF) by $P$. ostreatus at $25{ }^{\circ} \mathrm{C}$

\begin{tabular}{|c|c|c|c|c|c|c|c|c|c|c|c|c|c|c|}
\hline \multirow[b]{2}{*}{ Substrate } & \multicolumn{7}{|c|}{ Substrate Composition } & \multicolumn{7}{|c|}{ Fermented Substrate Composition } \\
\hline & Molasses & MSR & BSG & Whey & $\begin{array}{l}\text { Potato } \\
\text { Pulp }\end{array}$ & $\begin{array}{c}\text { Orange } \\
\text { Pulp }\end{array}$ & Water & $\begin{array}{c}\text { Initial } \\
\text { Protein }\end{array}$ & $\begin{array}{c}\text { Final } \\
\text { Protein }\end{array}$ & $\begin{array}{l}\text { Protein } \\
\text { Increase }\end{array}$ & $\begin{array}{l}\text { Initial } \\
\text { Sugar }\end{array}$ & $\begin{array}{l}\text { Final } \\
\text { Sugar }\end{array}$ & $\begin{array}{c}\text { Sugar } \\
\text { Reduction }\end{array}$ & Moisture \\
\hline & $\mathbf{m L}$ & g & $\mathrm{g}$ & $\mathrm{mL}$ & $\mathbf{m L}$ & $\mathrm{mL}$ & $\mathrm{mL}$ & $\% w / w$ & $\% w / w$ & $\%$ & $\mathrm{~g} / \mathrm{Kg}$ & $\mathrm{g} / \mathrm{Kg}$ & $\%$ & $\%$ \\
\hline S1 & 5 & 5 & 50 & 5 & 5 & 5 & 20 & 19.3 & 44.2 & 24.9 & 8.9 & 0.4 & 95.5 & 86.7 \\
\hline S2 & 5 & 5 & 50 & 5 & 5 & 5 & 20 & 15.5 & 39.2 & 23.7 & 9.3 & 1.2 & 87.1 & 78.9 \\
\hline S3 & 5 & 12.5 & 5 & 5 & 5 & 5 & 20 & 15.5 & 32.6 & 17.1 & 17.1 & 0.4 & 97.7 & 84.7 \\
\hline S4 & 5 & 13 & 5 & 5 & 5 & 50 & 20 & 25.7 & 39.8 & 14.1 & 30.6 & 0.6 & 98.2 & 84.6 \\
\hline S5 & 5 & 5 & 5 & 5 & 50 & 5 & 20 & 40.4 & 58.8 & 18.4 & 22.4 & 1.5 & 93.3 & 90.5 \\
\hline S6 & 5 & 5 & 30 & 5 & 5 & 20 & 20 & 27.8 & 49.3 & 21.5 & 15.6 & 3.0 & 80.5 & 64.7 \\
\hline S7 & 20 & 5 & 30 & 5 & 20 & 5 & 20 & 16.8 & 43.2 & 26.4 & 34.0 & 0.0 & 100.0 & 58.4 \\
\hline S8 & - & - & 30 & - & - & 30 & 20 & 33.3 & 43.8 & 10.5 & 4.9 & 2.6 & 46.8 & 88.0 \\
\hline S9 & - & 30 & - & - & - & 30 & 20 & 32.9 & 34.6 & 1.7 & 5.5 & 0.9 & 83.3 & 87.3 \\
\hline $\mathrm{S} 10$ & 30 & - & - & - & - & 30 & 20 & 12.8 & 28.9 & 16.1 & 24.5 & 0.0 & 100.0 & 68.5 \\
\hline S11 & - & - & - & 10 & - & 30 & 20 & 30.7 & 35.2 & 4.5 & 9.2 & 3.3 & 64.0 & 88.0 \\
\hline $\mathrm{S} 12$ & - & - & - & - & 30 & 30 & 20 & 37.2 & 59.8 & 22.6 & 8.9 & 0.2 & 98.2 & 82.2 \\
\hline $\mathrm{S} 13$ & 30 & - & 30 & - & - & - & 20 & 13.7 & 13.8 & 0.1 & 30.6 & 17.6 & 42.4 & 72.1 \\
\hline S14 & 30 & 20 & - & - & - & - & 20 & 17.7 & 17.8 & 0.1 & 33.2 & 21.3 & 35.6 & 82.2 \\
\hline S15 & - & - & 30 & - & 30 & - & 20 & 31.0 & 31.6 & 0.6 & 3.6 & 0.0 & 99.4 & 82.5 \\
\hline S16 & - & 20 & 30 & - & - & - & 20 & 24.2 & 45.0 & 20.8 & 1.1 & 0.9 & 20.0 & 82.9 \\
\hline S17 & 20 & - & 45 & - & - & - & 20 & 24.3 & 31.5 & 7.2 & 22.9 & 0.0 & 100.0 & 77.2 \\
\hline $\mathrm{S} 18$ & - & - & 50 & 15 & - & - & 20 & 40.5 & 56.0 & 15.5 & 2.0 & 0.6 & 72.0 & 81.3 \\
\hline S19 & - & 20 & - & - & 10 & - & 20 & 40.3 & 42.6 & 2.3 & 0.2 & 0.2 & 8.7 & 81.9 \\
\hline S20 & 20 & 20 & - & - & - & - & 20 & 29.7 & 30.9 & 1.2 & 11.2 & 3.1 & 72.2 & 85.5 \\
\hline S21 & - & 20 & - & 60 & - & - & 20 & 27.9 & 34.4 & 6.5 & 5.7 & 2.1 & 62.3 & 81.1 \\
\hline S22 & - & - & 30 & 10 & 30 & - & 20 & 23.8 & 45.3 & 21.5 & 2.0 & 1.1 & 44.4 & 81.0 \\
\hline $\mathrm{S} 23$ & - & 20 & - & 70 & 35 & - & 20 & 32.3 & 53.7 & 21.4 & 3.6 & 0.4 & 88.8 & 81.8 \\
\hline S24 & - & 20 & 20 & 70 & - & - & 20 & 42.6 & 58.5 & 15.9 & 2.2 & 1.2 & 48.7 & 79.8 \\
\hline S25 & - & 20 & 20 & - & 30 & - & 20 & 32.8 & 51.4 & 18.6 & 1.2 & 0.6 & 48.7 & 82.2 \\
\hline
\end{tabular}


All of the substrates were analyzed for initial crude protein content. The substrates were sterilized at $120{ }^{\circ} \mathrm{C}$ for $15 \mathrm{~min}$. Amounts of $30 \mathrm{~g}$ of each substrate were spread in pre-weighed Petri dishes. From plates containing P. ostreatus mycelia grown on MEA, 3 pieces of $10 \times 10 \mathrm{~mm}$ of agar with mycelia were cut and were vortexed into $30 \mathrm{~mL}$ Ringer's solution to remove the basidiospores. Aliquots of $1 \mathrm{~mL}$ of this suspension were used to inoculate the substrates. The cultures were incubated at $25^{\circ} \mathrm{C}$ for 7-12 days. The growth time was defined as the time that was needed for the white mycelia to cover the surface of each substrate. After that the substrates covered with mycelia were oven-dried at $100{ }^{\circ} \mathrm{C}$ for $10 \mathrm{~h}$ and the final protein content was determined. The growth of P. ostreatus was subsequently studied on the best substrate at 37,25 , and $15{ }^{\circ} \mathrm{C}$, and then at the optimum substrate, optimum incubation temperature, and at different $\mathrm{pH}$ values (4.0, 5.5, and 7.0). All of the experiments were performed in triplicate. Finally, P. ostreatus growth at larger scale was carried out at the optimum conditions, using different SSF set-ups: (a) polyethylene bags; (b) trays of $1 \mathrm{Kg}$ capacity; and, (c) plastic perforated cylindrical bioreactors. Amounts of $1 \mathrm{Kg}$ of sterilized substrate were placed into the three bioreactor types (in triplicate), and were inoculated, as described above, for the plate experiments. All systems were incubated at $25^{\circ} \mathrm{C}$ for 30 days. The substrates were checked daily to detect mycelium appearance, and then small holes were opened in the bioreactors in order to allow for the possible occurrence of fruiting.

\subsection{Autolysis of the SSF Product}

Autolysis of the P. ostreatus SSF product (on the optimum substrate and growth conditions) was carried out by suspending in distilled water, adjusting the $\mathrm{pH}$ to 6.0 , and incubating at $50{ }^{\circ} \mathrm{C}$ in a water bath for $24 \mathrm{~h}$. The process was terminated by heating at $80^{\circ} \mathrm{C}$ for $30 \mathrm{~min}$. The suspension was centrifuged to remove the cell debris. The supernatant was concentrated in a water bath at $80^{\circ} \mathrm{C}$ and the concentrate was then freeze-dried to produce the extract powder. Freeze-drying was carried out by cooling to $-40{ }^{\circ} \mathrm{C}\left(3{ }^{\circ} \mathrm{C} / \mathrm{min}\right)$ and freeze-drying overnight at $5-15 \times 10^{-3} \mathrm{Bar}$ and $-50^{\circ} \mathrm{C}$ in a Freeze Dry System, Freezone 4.5 (Labconco, MO, USA).

\subsection{Assays}

Moisture, $\mathrm{pH}$, ash, and total fat were determined, as previously described $[9,10]$, with minor modifications. In brief, moisture $(\% w / w)$ was determined by drying at $80{ }^{\circ} \mathrm{C}$ overnight. $\mathrm{pH}$ was determined after suspending $10 \mathrm{~g}$ of sample in $100 \mathrm{~mL}$ water. Ash $(\% w / w)$ was determined by burning accurately weighed (1-2 g) amounts of the samples in porcelain crucibles on a burner flame, followed by ashing at $550{ }^{\circ} \mathrm{C}$ for at least $3 \mathrm{~h}$. Cheese whey was evaporated before burning. Total fat $(\% \mathrm{w} / \mathrm{w})$ was determined by the extraction of $5 \mathrm{~g}$ of dried sample $\left(105^{\circ} \mathrm{C} ; 3 \mathrm{~h}\right)$ with diethyl ether in a Soxhlet apparatus for about $2.5 \mathrm{~h}$. The extract was condensed in a rotary evaporator, dried at $105^{\circ} \mathrm{C}$ for $0.5 \mathrm{~h}$, and weighed $[9,10]$. In the case of cheese whey, the determination of fat was carried out according to the Gerber method for milk analysis, which involves the treatment with sulfuric acid and amyl alcohol for separation of fat, and measurement of the volume of fat after centrifugation.

Fermentable sugars (sucrose, fructose, lactose, glucose, galactose) and ethanol, were analyzed by HPLC on a Shimadzu (Kyoto, Japan) chromatograph that was equipped with a SCR-101N stainless steel column, a LC-9A pump, a CTO-10A oven (set at $60^{\circ} \mathrm{C}$ ), and a RID-6A refractive index detector. Water was used as mobile phase $\left(0.8 \mathrm{~mL} \mathrm{~min}^{-1}\right)$ and a $1 \% v / v$ 1-butanol solution (Merck) was used as internal standard.

Crude protein was analyzed according to the Kjeldahl's method for the determination of total nitrogen in milk [9]. The real protein increase (RPI) of the samples that was attributed to the microbial biomass was calculated using the formulas (Equations 1 and 2) [16]:

$$
R P=\frac{\left(M_{\text {final }} \times P_{\text {final }}\right)-\left(M_{\text {initial }} \times P_{\text {initial }}\right)}{M_{\text {initial }}}+P_{\text {initial }}
$$




$$
R P I=\frac{\left(\mathrm{RP}-P_{\text {initial }}\right)}{P_{\text {initial }}} \times 100
$$

in which $M_{\text {initial }}$ is the weight (g dry matter) before SSF, $P_{\text {initial }}$ is the initial protein content (\% dry matter), $M_{\text {final }}$ is the weight (g dry matter) after SSF, and $P_{\text {final }}$ is the final protein content (\% dry matter).

The determination of total phenolics in both organic (methanol) and the aqueous extracts of the samples was carried out spectrophotometrically, according to the Folin-Ciocalteau procedure $[9,17]$. Gallic acid solutions in methanol were used as standards. In brief, methanolic extracts of the samples were prepared after alkaline hydrolysis with $1 \mathrm{~N} \mathrm{NaOH}$, followed by centrifugation, acidification with conc. $\mathrm{HCl}$ to $\mathrm{pH} 2$, extraction with 1:1 diethyl ether/ethyl acetate, evaporation of the solvents, and finally, the dilution of the dry residue with $12 \mathrm{~mL}$ methanol. The total phenolics were determined by measuring the absorbance of the extract/Folin-Ciocalteu reagent mixture at $760 \mathrm{~nm}$ [17].

The determination of the antioxidant capacity in both organic (methanol) and the aqueous extracts was performed by the DPPH radical scavenging method, based on the decrease in absorbance at $517 \mathrm{~nm}$ of a methanolic solution of DPPH against aqueous methanol solution as blank [9,17].

The determination of COD was carried out by both a colorimetric test [reaction with $\mathrm{HgSO}_{4}$, $\mathrm{H}_{2} \mathrm{SO}_{4} / \mathrm{AgSO}_{4}$, and $\mathrm{K}_{2} \mathrm{Cr}_{2} \mathrm{O}_{7}$, and titration of excess $\mathrm{K}_{2} \mathrm{Cr}_{2} \mathrm{O}_{7}$ with $\mathrm{FeSO}_{4}\left(\mathrm{NH}_{4}\right)_{2} \mathrm{SO}_{4} \cdot 6 \mathrm{H}_{2} \mathrm{O}$ and ferroin indicator], according to standard methods [9,18], and a photometric test (using an electronic digestion device HACH DRB-200, a spectrophotometer HACH DR/2400, and digestion reagent vials HACH COD Digestion Vials, Low Range 3-150 mg/L COD) [9]. Metals Ca, Mg, Fe, and Cu were determined on a AA-6500 Series Atomic Absorption Spectrometer (Shimadzu) after ashing at $550{ }^{\circ} \mathrm{C}$ and dissolving in condensed nitric acid [10].

Major volatile compounds were determined by gas chromatography on a Shimadzu GC-8A system (Japan) with a stainless steel column TRB-624 (Teknokroma, Barcelona, Spain) (30 m, $0.32 \mathrm{~mm}$ i.d.; temperature $40-200{ }^{\circ} \mathrm{C}$ by $\left.10{ }^{\circ} \mathrm{C} / \mathrm{min}\right)$, He as carrier gas $\left(23 \mathrm{~cm}^{3} / \mathrm{s}\right)$, and a Flame Ionization Detector (FID). The injection port and the detector temperatures were $260^{\circ} \mathrm{C}$. Samples of $2 \mu \mathrm{L}$ were injected directly into the column and quantification was done using calibration curves. The composition of headspace volatile compounds of the treated substrates after SSF was analyzed by solid-phase micro-extraction (SPME) gas chromatography mass spectrometry (GC/MS) on a Shimadzu GC-17A gas chromatograph (capillary column Supelco CO Wax-10 $60 \mathrm{~m}, 0.32 \mathrm{~mm}$ i.d., $0.25 \mu \mathrm{m}$ film thickness) coupled to a Shimadzu MS QP5050 mass spectrometer (70 eV ionization energy; 30-400 $\mathrm{m} / \mathrm{z}$ mass range) [10]. The fiber that was used for absorption of volatiles was a 50/30 $\mu \mathrm{m}$ DVB/Carboxen/PDMS StableFlex for manual holder (Supelco, Bellefonte, PA, USA). For the SPME sampling, $5 \mathrm{~g}$ of sample were transferred to a sealed $20 \mathrm{~mL}$ glass vial, stirred for $5 \mathrm{~min}$ at $60{ }^{\circ} \mathrm{C}$, and the fiber was then exposed to the headspace for $45 \mathrm{~min}$. Injection in the GC was performed in splitless mode. The oven temperature program was: $40^{\circ} \mathrm{C}$ for $5 \mathrm{~min}$; rise to $110^{\circ} \mathrm{C}$ by $10^{\circ} \mathrm{C} / \mathrm{min}$; rise to $180^{\circ} \mathrm{C}$ by $2{ }^{\circ} \mathrm{C} / \mathrm{min}$; rise to $250^{\circ} \mathrm{C}$ by $10^{\circ} \mathrm{C} / \mathrm{min}$; and, held for $6 \mathrm{~min}$. Identification was carried out by comparing the retention times and mass spectra of volatiles to those of pure compounds (Sigma-Aldrich, Poole, UK), by mass spectra that were obtained from NIST107, NIST21, and SZTERP libraries, and by determining the Kovats' retention indexes and comparing with those that were reported in the literature [10].

The extract produced after autolysis and freeze-drying of the P. ostreatus SCP was analyzed for RNA content, using the orcinol method, as described by Herbert et al. [19], with some modifications. In brief, the samples were extracted with $0.5 \mathrm{M}$ perchloric acid for $90 \mathrm{~min}$ at $38^{\circ} \mathrm{C}$ with shaking, and centrifuged; the supernatant contains all of the RNA thatcan be determined by the orcinol reagent (aqueous $0.1 \mathrm{~g} / \mathrm{L}$ orcinol and $0.9 \mathrm{~g} / \mathrm{L} \mathrm{FeC1}_{3} \cdot 6 \mathrm{H}_{2} \mathrm{O}$ in conc. $\mathrm{HCl}$; ratio $1: 4$; used immediately after preparation). RNA gives a color with the orcinol reagent at the standard heating time of $20 \mathrm{~min}$, which is exactly equivalent to its content of purine-bound ribose. The absorbance was measured at $670 \mathrm{~nm}$ and the RNA content was calculated from a curve that was based on the reaction of the orcinol reagent with standard D-ribose solutions. 


\section{Results and Discussion}

\subsection{Composition of the AISS}

The sugar, protein, fiber, and mineral content of the sixAISS samples, as well as the presence of minor compounds, such as vitamins and trace elements, makes them suitable for microbial conversion. Previous analysis of these exact substrates showed that BSG, MSR, and cheese whey had a considerable protein content of about 31, 24, and $14 \% w / w$ (on dry matter), respectively [9]. In brief, molasses, orange, and potato pulps had lower amounts of protein (av. 7.3, 2.9, and $2.5 \% w / w$ on dry matter, respectively) [9]. Molasses contained the highest amount of fermentable sugar (42.5\%w/w), while orange pulp had the highest amount of phenolics content $(15.8 \mathrm{mg} / \mathrm{g}$ dry matter in aqueous extract, and 5\% $\mathrm{mg} / \mathrm{g} \mathrm{DM}$ in organic extract) [9]. On the other hand, despite the total phenolic content, cheese whey presented the highest antioxidant capacity $\left(4.35 \mathrm{mg} / \mathrm{mL} \mathrm{IC}_{50}\right)$ [9]. In this study, the analysis of $\mathrm{Ca}, \mathrm{Mg}$, Fe, and $\mathrm{Cu}$ (Table 2) showed that molasses had the highest minerals content (Ca and $\mathrm{Mg}$ ) and orange pulp had the lowest. MSR also contained significant amounts of $\mathrm{Mg}$, as reported in previous studies [20]. BSG also had a considerably high content of these minerals. Whey was found to be rich in $\mathrm{Mg}$ ( $2 \mathrm{~g} / \mathrm{kg}$ ), however, when compared with the concentrations that were reported in other publications, there seem to be discrepancies. The results that were obtained in this study are similar to those reported by Glass and Hendrick [21] with respect to Fe and $\mathrm{Cu}$, but significantly higher than other references [22-24] regarding $\mathrm{Mg}$. These differences are expected due to the different raw materials (milk) and different production process. BSG were also found to be rich in $\mathrm{Mg}$. Also, the amount of $\mathrm{Cu}$ contained was much higher than that required daily by the human body [25], while the content of Fe was significantly lower [26]. It has been reported that BSG contain significant amounts of minerals and trace elements and are therefore suitable substrates for the production enzymes by SSF [27]. In the case of the other two metals, there are differences in the levels, which may be due to the way barley that is cultivated, the different harvest time, and the beer production process [27]. Table 2 shows that the orange pulp has a high Ca content, the second largest among the six AISS, and at the same time, the lowest $\mathrm{Mg}$ content. Still, the percentage of $\mathrm{Cu}$ that is contained in orange pulp is low ( $1 \mathrm{Kg}$ of pulp would be required to cover the average daily diet requirements). Wide variations in the orange composition have also been reported in the literature, which are affected by several factors, including availability in soil, soil $\mathrm{pH}$, uptake ability of the plant, use of fertilizers, irrigation water, etc. [28]. Finally, potato pulp seems to be another good source of $\mathrm{Mg}$ since its percentage is quite high. On the other hand, Fe was not detected, which is not in line with the common knowledge that potatoes are rich sources of iron [29,30]. However, there are also discrepancies in the literature, which may also be attributed to the different soil composition, plant physiology and agricultural practices.

Table 2. Metal elements contained in the used AISS.

\begin{tabular}{ccccccc}
\hline Metal (mg/Kg) & MSR & BSG & Whey & Molasses & Orange Pulp & Potato Pulp \\
\hline $\mathrm{Mg}$ & 3970 & 605.6 & 2000 & 14,200 & 0.19 & 320.63 \\
$\mathrm{Ca}$ & 20.30 & 4.39 & 21.0 & 1636 & 285 & 1.10 \\
$\mathrm{Fe}$ & 96.02 & 4.56 & 0 & 70.9 & - & - \\
$\mathrm{Cu}$ & 19.38 & 24.62 & 3.66 & 6.03 & 3.21 & 3.34 \\
\hline
\end{tabular}

\subsection{P. ostreatus Growth in the Mixed AISS}

In Table 3, the protein and sugar composition of the mixed AISS substrates before and after the growth of $P$. ostreatus by SSF at $25^{\circ} \mathrm{C}$, are presented. The moisture content of the substrates after fermentation was $62.6-88.7 \%$, which is suitable for P. ostreatus growth. The fungus consumed most of the fermentable sugar in most cases. The reduction of sugars and the increase of protein are illustrated in Figure 1. The highest protein increase can be observed for the S7 substrate $(5 \mathrm{~mL}$ whey, $20 \mathrm{~mL}$ molasses, $5 \mathrm{~mL}$ orange pulp, $20 \mathrm{~mL}$ potato pulp, $30 \mathrm{~g} \mathrm{BSG}, 5 \mathrm{~g}$ MSR, and $20 \mathrm{~mL}$ water), which also had 
the highest sugar consumption. Generally, P. ostreatus was able to grow on all of the substrates, which indicates the suitability of the mixed AISS as substrates for edible mushroom growth.

Table 3. Effect of temperature $\left(15,25\right.$, and $\left.37^{\circ} \mathrm{C}\right)$ and $\mathrm{pH}(4.0,5.5$, and 7.0$)$ on P. ostreatus growth in $\mathrm{S} 7$ by SSF.

\begin{tabular}{|c|c|c|c|c|c|c|c|}
\hline $\mathrm{pH}$ & Temp. & Initial Sugar & Final Sugar & Final Protein & Yield & Final ash & Moisture \\
\hline 4.0 & 25 & 30.04 & 0.15 & 27.96 & 59.44 & 1.10 & 63.2 \\
\hline 7.0 & 25 & 31.17 & 0.20 & 38.35 & 39.50 & 0.82 & 62.6 \\
\hline 4.0 & 15 & 21.04 & 8.75 & 27.96 & 41.84 & 0.70 & 87.5 \\
\hline
\end{tabular}

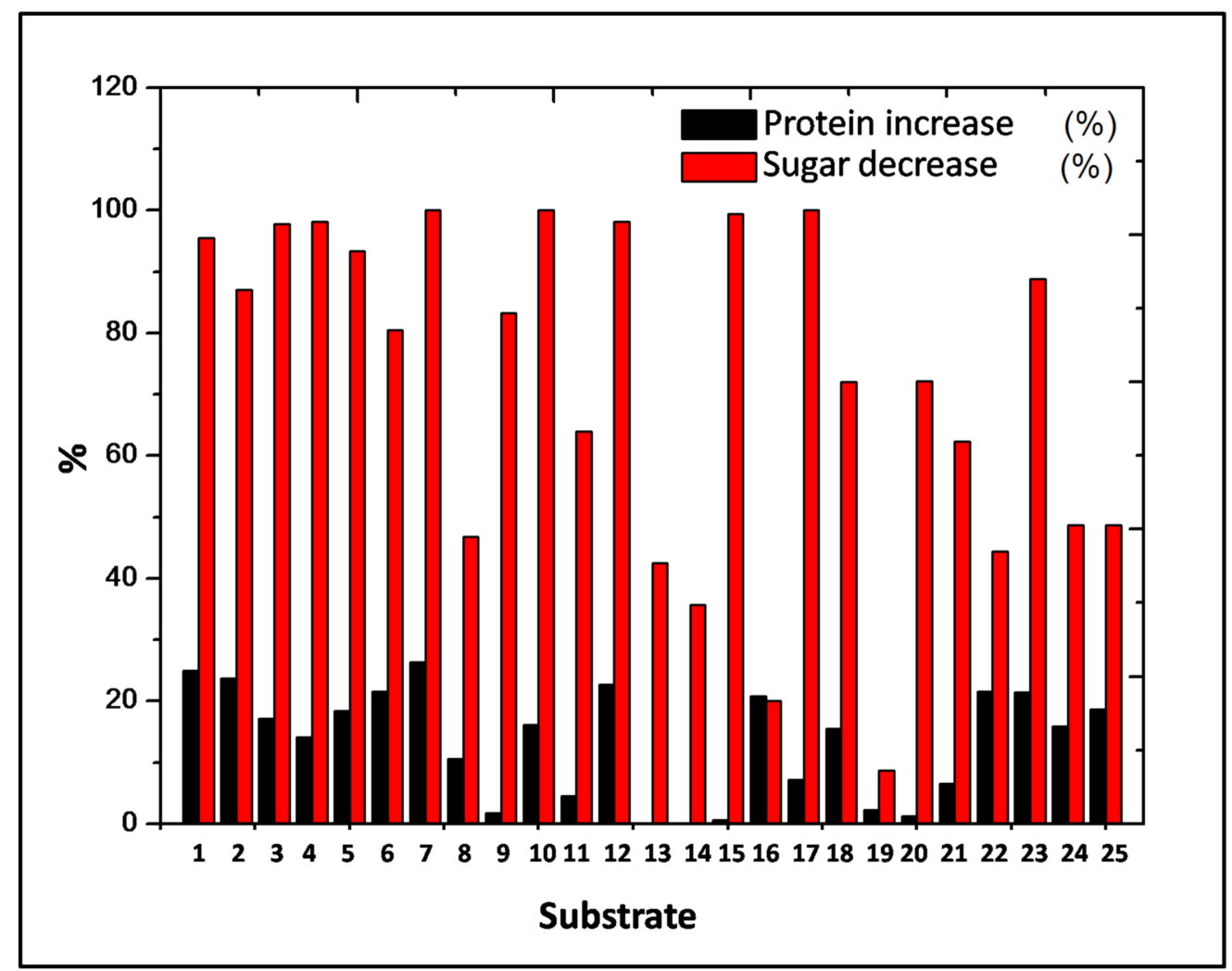

Figure 1. Sugar consumption and protein increase during P. ostreatus growth in the 25 mixed AISS substrates.

Subsequently, the effects of substrate $\mathrm{pH}\left(4.0,5.5\right.$, and 7.0 , at $\left.25^{\circ} \mathrm{C}\right)$ and temperature $(15,25$, and $37^{\circ} \mathrm{C}$, at $\mathrm{pH} 4.0$ ) on P. ostreatus growth on substrate S7 were studied. In this case, the biomass yield was expressed as $\mathrm{g}$ of mycelium $/ \mathrm{Kg}$ of substrate, and the results are presented in Table 3. Higher mycelial yield was achieved at $\mathrm{pH} 4.0$, while the lowest was at $\mathrm{pH}$ 7.0. This was expected as the optimal $\mathrm{pH}$ values for the growth of Pleurotus fungi range from 4.0 to 6.5 [31]. From Table 3, it can also be seen that the fungus grows better at $25^{\circ} \mathrm{C}$. This is confirmed by other works that identified the optimal growth temperature of $P$. ostreatus to be about $22^{\circ} \mathrm{C}$ [32-34].

For the scale-up experiments, the growth of P. ostreatus on the $\mathrm{S} 7$ substrate was then studied using three different bioreactor systems, as described in paragraph 2.2. After two days of incubation, the formation of mycelium appeared in all three systems, and at five days, it had covered the entire surface of the substrate. The incubation temperature was then reduced to $16^{\circ} \mathrm{C}$ to facilitate the fruiting 
of the mushrooms, since the optimum temperature reported in the literature is $15-18{ }^{\circ} \mathrm{C}$ [32-34]. The incubation was continued for a further 35 days during which (every seven days) water was added to maintain stable substrate moisture. At the end of the 40 days of incubation, no appearance of fruit from the edible fungus was observed, but the mycelium, on the contrary, showed alterations in color and gas (probably methane) formation. Thus, further research is needed on the conditions (moisture, temperature, addition on trace elements, etc.) for mushroom fruiting bodies using the proposed mixed AISS.

\subsection{Composition of the SSF Product and Autolyzate}

The product of SSF of the mixed AISS (substrate S7) by P. ostreatus was analyzed for protein, total fat, ash, essential elements $(\mathrm{Ca}, \mathrm{Mg}, \mathrm{Fe}, \mathrm{Cu})$, and volatiles content (Table 4). The protein and fat levels were relatively high, higher than those that were reported in other works for fermented barley or dry citrus pulps [35-37], which makes the enriched material a potential nutritious food and feed supplement. The protein content was also higher when compared to that of the same AISS substrates that were fermented by SSF with kefir $(23.6 \%)$, and slightly lower than those that were fermented by S. cerevisiae and K. marxianus ( $38.4 \%$ and $33.7 \%$, respectively) [10]. The fat content $(14.4 \%)$ was slightly higher than those of the S. cerevisiae and kefir fermented AISSs (12.9\% and $12.3 \%$, respectively), but lower than that of K. marxianus (25.5\%) [10]. Regarding the minerals content, the P. ostreatus SSF product had similar amounts of $\mathrm{Ca}$ and $\mathrm{Cu}$ content with those of S. cerevisiae, kefir, and K. marxianus [10], but much higher Fe content when compared with these products $(0.9-2.3 \mathrm{mg} / \mathrm{Kg})$ [10]. Regarding $\mathrm{Mg}$, the substrate that was fermented by $S$. cerevisiae contained the highest content of all compared products $(771.1 \mathrm{mg} / \mathrm{Kg})$ [10]. In general, it can be said that these essential minerals were found in significant amounts in the fermented AISS products.

Table 4. Composition of the product of S7 SSF by P. ostreatus and its autolyzate.

\begin{tabular}{ccc}
\hline & Characteristic & Content \\
\hline & Moisture & $76.0 \pm 2.3$ \\
Dry matter & $24.0 \pm 2.1$ \\
Protein $(\% w / w)$ & $30.3 \pm 1.9$ \\
Ash $(\% w / w)$ & $0.93 \pm 0.1$ \\
Fat $(\% w / w$ dry matter $)$ & $14.4 \pm 1.1$ \\
Ca $(\mathrm{mg} / \mathrm{Kg})$ & $91.1 \pm 8.3$ \\
& $\mathrm{Mg}(\mathrm{mg} / \mathrm{Kg})$ & $324.5 \pm 24.1$ \\
& $\mathrm{Fe}(\mathrm{mg} / \mathrm{Kg})$ & $17.8 \pm 2.1$ \\
$\mathrm{Cu}(\mathrm{mg} / \mathrm{Kg})$ & $21.8 \pm 2.1$ \\
\hline Major volatile compounds $(\mathrm{mg} / \mathrm{Kg})(\mathrm{GC} / \mathrm{FID})$ & \\
& Acetaldehyde & $277.7 \pm 26.3$ \\
& Ethyl acetate & $142.4 \pm 18.7$ \\
& Propan-1-ol & $21.5 \pm 3.2$ \\
& Isobutyl alcohol & $31.9 \pm 4.3$ \\
Amyl alcohols & $7.5 \pm 1.3$ \\
\hline SSF product after autolysis & RNA (mg/100 g dry extract) & $721.8 \pm 31.9$ \\
\hline
\end{tabular}

The composition of headspace volatile compounds that were identified by SPME GC/MS (totally 30 different compounds) in the same AISS as well as in their mixtures fermented by S. cerevisiae, K. marxianus, and kefir, has been reported in a previous study [10]. The volatile compounds that contribute to the aroma of fermented products are produced during fermentation or derive from the raw materials. Some of the major volatile by-products that are produced by fermentation are acetaldehyde, ethyl acetate, propan-1-ol, isobutanol, and amyl alcohols (Table 4). These compounds were all found (by GC/FID analysis) in the SSF product of P. ostreatus, especially acetaldehyde, which was found at relatively high levels. Acetaldehyde has a pungent, etherial, fruity, or musty odor, depending on its concentration. Also, it may accumulate during mushroom growth at high temperatures due to anaerobic respiration and can have an inhibitory effect on mushroom growth 
(Spawn-burning syndrome) [38]. Therefore, inefficient oxygen supply may be the reason for the high acetaldehyde levels and the inability of the mushroom to grow fruiting bodies, and, in the future, further research will be needed focusing on the optimization of growth temperature and oxygen supply for scale-up of edible mushrooms production on these AISS.

Similar but fewer compounds were (positively) that were identified by SPME GC/MS analysis of the headspace of the P. ostreatus AISS fermentation product (Table 4). The principal compounds that are responsible for the aroma of raw and thermally processed mushrooms are aliphatic alcohols and ketones with eight carbon atoms [39]. However, only 1-octen-3-ol was positively identified. p-Xylene (1,4-dimethylbenzene) was possibly identified as a degradation product of aromatic amino acids, such as phenylalanine [40], as it usually found in other fermented and ripened products, such as cheese [41]. The presence of C6, C7, and C9 carbonylic compounds (2-hexanone, 3-heptanone, 2-heptanone, 5-nonanone) can be related to fatty acids oxidation [42]. Especially, methylketones, such as 2-hexanone and 2-heptanone, are very typical products of fungal species, biosynthesized by decarboxylation of $\beta$-keto-acids that are produced by $\beta$-oxidation of free fatty acids. 1,1,3,5-Tetramethyl-cyclohexane has also been previously identified in food as a result of microbial spoilage [42]. Finally, methyl pentanoate esters, such as isopropyl valerate, also occur naturally in fermented beverages, fruits, and vegetables $[43,44]$.

The P. ostreatus SSF product of substrate S7 was autolyzed, freeze-dried, powdered, and analyzed for total RNA content. The texture of the powder was similar to that of commercial yeast extract. It contained about $722 \mathrm{mg}$ total RNA/100 $\mathrm{g}$ of dry powder, which was similar to that reported for K. marxianus grown on whey [45]. RNA is a component of microbial extracts, which, after partial hydrolysis, provides oligonucleotides that can enhance the flavor and taste (umami) when used as additives in food [45].

\section{Conclusions}

The mixed AISS substrate for which the highest sugar consumption, protein increase, and P. ostreatus mycelium yield were observed, consisted of $20 \mathrm{~mL}$ molasses (diluted to $4^{\circ}$ Baume density), $20 \mathrm{~mL}$ potato pulp, $5 \mathrm{~mL}$ whey, $5 \mathrm{~mL}$ orange pulp, $30 \mathrm{~g} \mathrm{BSG}$, and $5 \mathrm{~g}$ MSR (at $25^{\circ} \mathrm{C}$ and substrate $\mathrm{pH} 4$ ). In all of the experiments, orange pulp and BSG seemed to act as growth promoting ingredients. The produced fermented mycelium-enriched product was rich in protein, minerals (mainly Mg), and aroma volatile compounds, indicating the potential for use as protein-rich nutritious supplement for food, feed, or microbiology uses. High acetaldehyde levels were observed, which possibly inhibited the fruiting of the mushroom. Finally, the autolyzed dried product had high total ribonucleic acid content showing potential for use as natural food flavor enhancer. Future research will be needed focusing on optimization of growth temperature and oxygen supply for the scale-up of edible mushrooms production on these AISS, as well as the use of the autolyzed enriched substrates as food flavor enhancers and microbiology extracts.

Acknowledgments: This work was supported by the Research Committee of the University of Patras, Greece (Program K. Karatheodori 2010, Project No. C916).

Author Contributions: Theodoros Aggelopoulos carried out the experimental work in the frame of PhD thesis, assisted and instructed by Argyro Bekatorou and Stavros Plessas. Athanasios A. Koutinas supervised the thesis and participated in setting-up the experimental design along with Argyro Bekatorou. Poonam Nigam provided expertise and resources regarding ligninolytic fungi.

Conflicts of Interest: The authors declare no conflict of interest.

\section{References}

1. Tripodo, M.M.; Lanuzza, F.; Micali, G.; Coppolino, R.; Nucita, F. Citrus waste recovery: A new environmentally friendly procedure to obtain animal feed. Bioresour. Technol. 2004, 91, 111-115. [CrossRef] 
2. Plessas, S.; Koliopoulos, D.; Kourkoutas, Y.; Psarianos, C.; Alexopoulos, A.; Marchant, R.; Banat, I.M.; Koutinas, A.A. Upgrading of discarded oranges through fermentation using kefir in food industry. Food Chem. 2008, 106, 40-49. [CrossRef]

3. Santos, M.; Jiménez, J.J.; Bartolomé, B.; Gómez-Cordovés, C.; Del Nozal, M.J. Variability of brewers' spent grain within a brewery. Food Chem. 2003, 80, 17-21. [CrossRef]

4. Branyik, T.; Vicente, A.A.; Machado-Cruz, J.M.; Teixeira, J.A. Spent grains-A new support for brewing yeast immobilization. Biotechnol. Lett. 2001, 23, 1073-1078. [CrossRef]

5. Bekatorou, A.; Bountas, Y.; Banat, I.M.; Kanellaki, M. Upgrading brewer's spent grains by treatment with Aspergillus species. Chem. Ind. Chem. Eng. Q. 2007, 13, 72-78. [CrossRef]

6. Koutinas, A.A.; Papapostolou, H.; Dimitrellou, D.; Kopsahelis, N.; Katechaki, E.; Bekatorou, A.; Bosnea, L.A. Whey valorisation: A complete and novel technology development for dairy industry starter culture production. Bioresour. Technol. 2009, 100, 3734-3739. [CrossRef] [PubMed]

7. Nigam, P.; Vogel, M. Bioconversion of sugar industry by-products-Molasses and sugar beet pulp for single cell protein production by yeasts. Biomass Bioenergy 1991, 1, 339-345. [CrossRef]

8. Gélinas, P.; Barrette, J. Protein enrichment of potato processing waste through yeast fermentation. Bioresour. Technol. 2007, 98, 1138-1143. [CrossRef] [PubMed]

9. Aggelopoulos, T.; Bekatorou, A.; Pandey, A.; Kanellaki, M.; Koutinas, A.A. Discarded oranges and brewer's spent grains as promoting ingredients for microbial growth by submerged and solid state fermentation of agro-industrial waste mixtures. Appl. Biochem. Biotechnol. 2013, 170, 1885-1895. [CrossRef] [PubMed]

10. Aggelopoulos, T.; Katsieris, K.; Bekatorou, A.; Pandey, A.; Banat, I.M.; Koutinas, A.A. Solid state fermentation of food waste mixtures for single cell protein, aroma volatiles and fat production. Food Chem. 2014, 145, 710-716. [CrossRef] [PubMed]

11. Jinap, S.; Hajeb, P. Glutamate: Its applications in food and contribution to health. Appetite 2010, 55, 1-10. [CrossRef] [PubMed]

12. Williams, A.N.; Woessner, K.M. Monosodium glutamate allergy. Menace or myth? Clin. Exp. Allergy 2009, 39, 640-646. [CrossRef] [PubMed]

13. Mortensen, A.; Aguilar, F.; Crebelli, R.; Di Domenico, A.; Dusemund, B.; Frutos, M.J.; Galtier, P.; Gott, D.; Gundert-Remy, U.; Leblanc, J.; et al. Re-evaluation of glutamic acid (E620), sodium glutamate (E621), potassium glutamate (E622), calcium glutamate (E623), ammonium glutamate (E624) and magnesium glutamate (E625) as food additives. EFSA J. 2017, 15, 4910.

14. Tanguler, H.; Erten, H. Utilization of spent brewer's yeast for yeast extract production by autolysis: The effect of temperature. Food Bioprod. Proc. 2008, 86, 317-321. [CrossRef]

15. Cavallo, N.; De Angelis, M.; Calasso, M.; Quinto, M.; Mentana, A.; Minervini, F.; Cappelle, S.; Gobbetti, M. Microbial cell-free extracts affect the biochemical characteristics and sensorial quality of sourdough bread. Food Chem. 2017, 237, 159-168. [CrossRef] [PubMed]

16. Iluyemi, F.B.; Hanafi, M.M.; Radziah, O.; Kamarudin, M.S. Fungal solid state culture of palm kernel cake. Bioresour. Technol. 2006, 97, 477-482. [CrossRef] [PubMed]

17. Gardeli, C.; Papageorgiou, V.; Mallouchos, A.; Kibouris, T.; Komaitis, M. Essential oil composition of Pistacialentiscus L. and Myrtuscommunis L.: Evaluation of antioxidant capacity of methanolic extracts. Food Chem. 2008, 107, 1120-1130. [CrossRef]

18. Eaton, A.D.; Clesceri, L.S.; Greenberg, A.E.; Franson, M.A.H. Standard Methods for the Examination of Water and Wastewater; American Public Health Association: Washington, DC, USA, 1995.

19. Herbert, D.; Phipps, P.J.; Strange, R.E. Chapter III. Chemical analysis of microbial cells. Methods Microbiol. 1971, 5, 209-344.

20. Liu, D.J.; Pomeranz, Y.; Robbins, G.S. Mineral content of developing and malted barley. Am. Assoc. Cereal Chem. 1975, 52, 678-686.

21. Glass, L.; Hedrick, T.I. Nutritional composition of sweet-type and acid-type dry wheys. 1. Major factors including amino-acids. J. Dairy Sci. 1977, 60, 185-189. [CrossRef]

22. Wong, N.P.; La Croix, D.E.; McDonough, F.E. Minerals in whey and whey fractions. J. Dairy Sci. 1978, 61, 1700-1703. [CrossRef]

23. Mavropoulou, I.P.; Kosikowski, F.V. Composition, solubility and stability of whey powders. J. Dairy Sci. 1973, 56, 1128. [CrossRef] 
24. Goyal, N.; Gandhi, D.N. Comparative analysis of Indian paneer and cheese whey for electrolyte whey drink. World J. Dairy Food Sci. 2009, 4, 70-72.

25. Bost, M.; Houdart, S.; Oberli, M.; Kalonji, E.; Huneau, J.F.; Margaritis, I. Dietary copper and human health: Current evidence and unresolved issues. J. Trace Elem. Med. Biol. 2016, 35, 107-115. [CrossRef] [PubMed]

26. Menezes, E.A.; Oliveira, A.F.; Franca, C.J.; Souza, G.B.; Nogueira, A.R.A. Bioaccessibility of Ca, Cu, Fe, Mg, $\mathrm{Zn}$, and crude protein in beef, pork and chicken after thermal processing. Food Chem. 2018, 240, 75-83. [CrossRef] [PubMed]

27. Malu, S.P.; Andrew, C.; Abah, J.; Oko, O.J. Determination of heavy metals in brewer's spent grains obtained from Benue Brewery Limited (BBL), Makurdi, North Central Nigeria. J. Nat. Sci. Res. 2014, 4, 119-122.

28. Simpkins, W.A.; Louie, H.; Wu, M.; Harrison, M.; Goldberg, D. Trace elements in Australian orange juice and other products. Food Chem. 2000, 71, 423-433. [CrossRef]

29. Ozturk, E.; Atsan, E.; Polat, T.; Kara, K. Variation in heavy metal concentrations of potato (Solanum tuberosum L.) cultivars. J. Anim. Plant Sci. 2011, 21, 235-239.

30. Arvanitoyannis, I.S.; Vaitsi, O.; Mavromatis, A. Physico-chemical and sensory attributes in conjunction with multivariate analysis of two potato (Solanum tuberosum L.) cultivars after 90 days of storage: An exploratory authentication study. Int. J. Food Sci. Tech. 2008, 43, 1960-1970. [CrossRef]

31. Zadrazil, F. The ecology and industrial production of Pleurotus ostreatus, P. florida, P. cornucopiae and P. eryngii. Mushroom Sci. 1976, 9, 621-652.

32. Kües, U.; Liu, Y. Fruiting body production in basidiomycetes. Appl. Microbiol. Biot. 2000, 54, 141-152. [CrossRef]

33. Nyochembeng, L.M.; Beyl, C.A.; Pacumbaba, R.P. Optimizing edible fungal growth and biodegradation of inedible crop residues using various cropping methods. Bioresour. Technol. 2008, 99, 5645-5649. [CrossRef] [PubMed]

34. Rajarathnam, S.; Shashirekha, M.N.; Bano, Z. Biodegradative and biosynthetic capacities of mushrooms: Present and future strategies. Crit. Rev. Biotechnol. 1998, 18, 91-236. [CrossRef] [PubMed]

35. Mathot, P.; Debevere, C.; Walhain, P.; Baudart, E.; Théwis, A.; Brakel, J. Composition and nutritive value for rats of Aspergillus niger solid fermented barley. Anim. Feed Sci. Technol. 1992, 39, 227-237. [CrossRef]

36. Joshi, V.K.; Sandhu, D.K. Preparation and evaluation of an animal feed byproduct produced by solid-state fermentation of apple pomace. Bioresour. Technol. 1996, 56, 251-255. [CrossRef]

37. Bambidis, V.A.; Robinson, P.H. Citrus by-products as ruminant feeds: A review. Anim. Feed Sci. Technol. 2006, 128, 175-217. [CrossRef]

38. Zhang, R.Y.; Hu, D.D.; Zhang, Y.Y.; Goodwin, P.H.; Huang, C.Y.; Chen, Q.; Gao, W.; Wu, X.L.; Zou, Y.J.; $\mathrm{Qu}$, J.B.; et al. Anoxia and anaerobic respiration are involved in "spawn-burning" syndrome for edible mushroom Pleurotus eryngii grown at high temperatures. Sci. Hortic. 2016, 199, 75-80. [CrossRef]

39. Misharina, T.A.; Mukhutdinova, S.M.; Zharikova, G.G.; Terenina, M.B.; Krikunova, N.I.; Medvedeva, I.B. The composition of volatile components of dry cepe and oyster mushroom. Appl. Biochem. Microbiol. 2009, 45, 544-549. [CrossRef]

40. Xiao, D.R.; Liu, R.S.; He, L.; Li, H.M.; Tang, Y.L.; Liang, X.H.; Chen, T.; Tang, Y.J. Aroma improvement by repeated freeze-thaw treatment during Tuber melanosporum fermentation. Sci. Rep. 2015, 5, 17120. [CrossRef] [PubMed]

41. Sable, S.; Letellier, F.; Cottenceau, G. An analysis of the volatile flavour compounds in a soft raw goat milk cheese. Biotechnol. Lett. 1997, 19, 143-145. [CrossRef]

42. Bianchi, F.; Careri, M.; Mangia, A.; Mattarozzi, M.; Musci, M.; Concina, I.; Falasconi, M.; Gobbi, E.; Pardo, M.; Sberveglieri, G. Differentiation of the volatile profile of microbiologically contaminated canned tomatoes by dynamic headspace extraction followed by gas chromatography-mass spectrometry analysis. Talanta 2009, 77, 962-970. [CrossRef] [PubMed]

43. Korkmaz, A.; Hayaloglu, A.A.; Atasoy, A.F. Evaluation of the volatile compounds of fresh ripened Capsicum annuum and its spice pepper (dried red pepper flakes and isot). LWT Food Sci. Technol. 2017, 84, 842-850. [CrossRef]

44. Garruti, D.S.; Franco, M.R.B.; Aparecida, M.; da Silva, A.P.; Janzantti, N.S.; Alves, G.L. Assessment of aroma impact compounds in a cashew apple-based alcoholic beverage by GC-MS and GC-olfactometry. LWT Food Sci. Technol. 2006, 39, 373-378. [CrossRef] 
45. Belem, M.A.F.; Lee, B.H. Fed-batch fermentation to produce oligonucleotides from Kluyveromyces marxianus grown on whey. Process Biochem. 1999, 34, 501-509. [CrossRef] (CC BY) license (http://creativecommons.org/licenses/by/4.0/). 